\title{
Wykorzystanie techniki bimodalnej do transportu kontenerów i pojemników wymiennych
}

\begin{abstract}
$W$ artykule zaprezentowano możliwości zastosowania bimodalnej techniki transportu kombinowanego do przewozu kontenerów i innych pojemników wymiennych. Przedstawiono przykładowe koncepcje rozwiqzań taboru bimodalnego. Wykazano korzyści wynikajace z zastosowania techniki bimodalnej w przewozach kombinowanych, kolejowo-drogowych.
\end{abstract}

\section{Wstęp}

Zasadnicze zalety transportu bimodalnego na tle innych systemów transportu kombinowanego to zmniejszenie masy martwej w postaci platformy nośnej wagonu oraz zmniejszenie odległości między jednostkami ładunkowymi w składzie pociagu bimodalnego [ 1 i 2$]$.

Te korzystne cechy transportu bimodalnego można wykorzystać również $\mathrm{w}$ transporcie odpowiednio przystosowanych pojemników wymiennych, a w szczególności kontenerów, przewożąc je nie jak dotychczas na platformach kontenerowych, a bezpośrednio na odpowiednich wózkach kolejowych. Dane statystyczne dotyczące przewozów kombinowanych wykazują, że w transporcie tym zdecydowanie dominują przewozy kontenerów na platformach kontenerowych, a wśród różnych gabarytów kontenerów eksploatowanych w Europie przeważają zdecydowanie kontenery 20' i 40', których liczbę szacuje się na kilka milionów.

Wykorzystując do przewozu kontenerów technikę transportu bimodalnego, przy pionowym przeładunku kontenerów z taboru drogowego na kolejowy i odwrotnie, można osiągnąć szereg istotnych korzyści w postaci:

- zmniejszenia transportowanej masy martwej (masy taboru kolejowego),

- zmniejszenia nacisku zestawu kołowego na tor,

- zmniejszenia zużycia toru,

- zmniejszenia energii pobieranej przez lokomotywę,

- zmniejszenia zużycia elementów ciernych układu hamulcowego pociagu,

- zwiększenia ilości transportowanego ładunku.

\section{Parametry pociągu}

Poniżej przedstawiono porównanie parametrów konstrukcyjnych tradycyjnego pociagu kontenerowego $\mathrm{z}$ pociąiem kontenerowym bimodalnym.

Na rys. 1 i 2 przedstawiono kontenery 40' ładowne, posadowione na dwuosiowych platformach kontenerowych i wózkach bimodalnych.

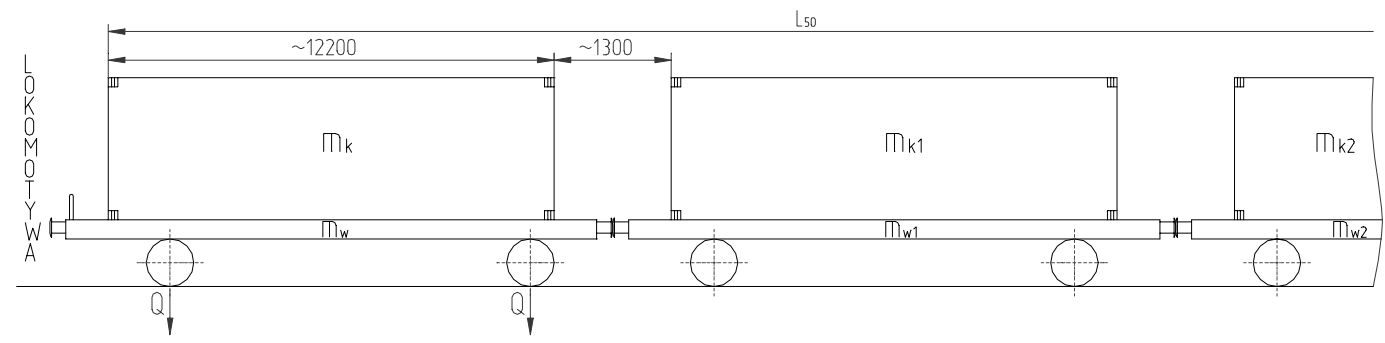

Rys. 1. Kontenery $40^{\prime} \mathrm{z}$ ładunkiem na platformach kontenerowych $m_{k}=34 t-$ masa kontenera $z$ tadunkiem, $m_{w}=\min 10 t-$ masa platformy kontenerowej, $Q=220 \mathrm{kN}$ - nacisk zestawu kołowego na tor, $L_{50}=\sim 674 \mathrm{~m}-$ dlugość pociagu dla 50 -ciu kontenerów.

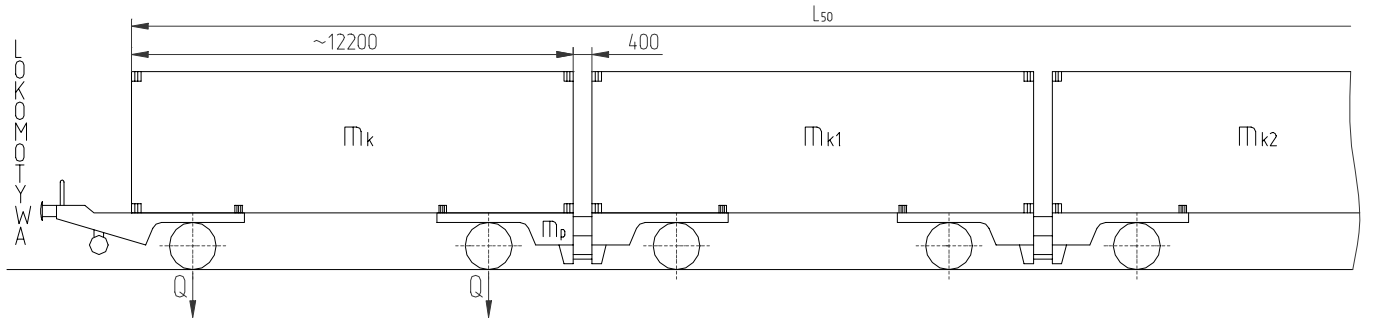

Rys.2. Kontenery 40' z ładunkiem na wózkach bimodalnych $m_{k}=34 t$-masa kontenera $z$ ladunkiem,

$m_{p}=3 t$-masa półwózka z zestawem kołowym,

$Q=200 \mathrm{kN}$ - nacisk zestawu kołowego na tor,

$L_{50}=\sim 630 \mathrm{~m}$-dlugość pociagu dla 50 -ciu kontenerów. 


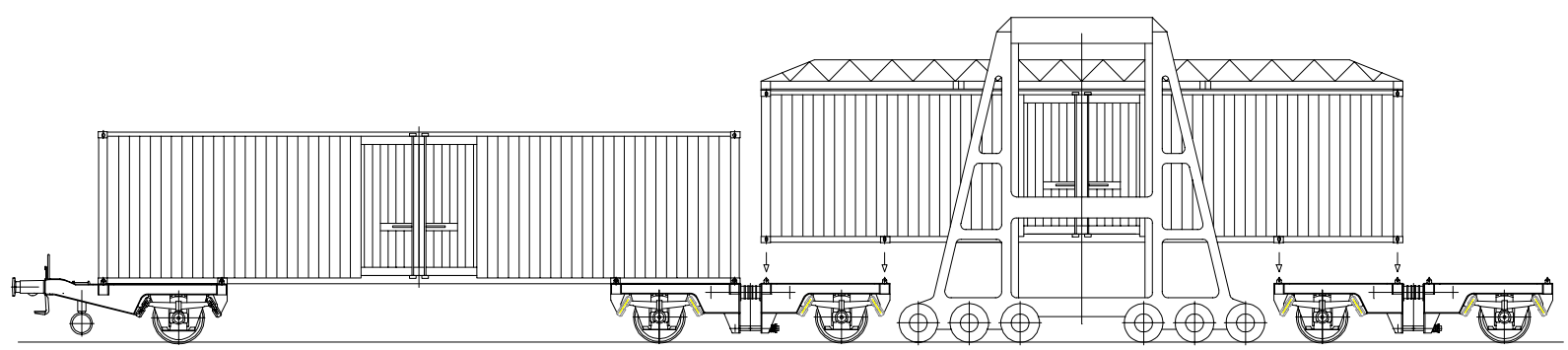

Rys.3. Przeładunek pionowy kontenera na wózki bimodalne

Celem spełnienia warunków bezpieczeństwa ruchu dla wagonów towarowych dwuosiowych określono w załączniku B.2.1. karty UIC 432 [3] minimalną mase wagonu 10 ton dla ruchu "SS" (120 km/h) i w załączniku A.2.1.1. 9 ton dla ruchu " $\mathrm{S}$ " $(100 \mathrm{~km} / \mathrm{h})$. Z minimalnej masy wagonu wynika najmniejszy dopuszczalny nacisk zestawu kołowego na tor, przy którym spełnione są jeszcze warunki bezpieczeństwa ruchu. Nacisk dla ruchu "SS" wynosi $\sim 50$ kN/oś, a dla ruchu "S" 45 kN/oś.

W przypadku transportu próżnych kontenerów na wózkach bimodalnych warunek ten jest również spełniony, ponieważ nacisk minimalny zestawu na tor w tym przypadku wynosi:

$$
\frac{m_{k p}+2 m_{p}}{2}=\frac{5 t+2 \cdot 3 t}{2}=5,5 t \approx 55 \mathrm{kN} / \text { os }
$$

gdzie:

$\mathrm{m}_{\mathrm{kp}}=5 \mathrm{t}$ - masa kontenera próżnego,

$\mathrm{m}_{\mathrm{p}}=3 \mathrm{t}-$ masa półwózka.

Z przedstawionego porównania wynika, że przy tej samej ilości transportowanego towaru, kontenerowy pociag bimodalny jest o około $44 \mathrm{~m}$ krótszy i 200 ton lżejszy w stanie załadowanym, od tradycyjnego pociagu kontenerowego złożonego z pięćdziesięciu czterdziestostopowych kontenerów.

Z przeprowadzonego porównania wynikają również wymienione $\mathrm{w}$ pkt 1 korzyści $\mathrm{z}$ wykorzystania taboru bimodalnego do transportu kontenerów.

Mniejsza masa martwa ma wpływ na zmniejszenie nacisku zestawu kołowego na tor z $220 \mathrm{kN}$ na $200 \mathrm{kN}$, co winno zaowocować mniejszym zużyciem kół zestawów kołowych oraz szyn toru i podtorza.

Winny pojawić się również oszczędności z tytułu kosztów utrzymania torów.

Mniejsza o 200 ton masa pociągu zmniejsza zapotrzebowanie na energię pobieraną przez lokomotywę, a hamowanie mniejszej masy wpłynie na mniejsze zużycie klocków hamulcowych i powierzchni tocznej kół.

W przypadku uformowania kontenerowego pociagu bimodalnego o długości zbliżonej do pociągu tradycyjnego, w pociągu bimodalnym można ilość transportowanych kontenerów zwiększyć o $\sim 3$ kontenery, przy mniejszej o 80 $\mathrm{t}$ masie pociągu bimodalnego, w porównaniu $\mathrm{z}$ tradycyjnym 50-cio wagonowym.

Przewidywane korzyści wskazują jednoznacznie na uzasadnioną celowość rozwoju przedstawionej koncepcji transportu kontenerów, a istniejąca sieć terminali ułatwi szybkie wdrożenie systemu do eksploatacji.

Rys. 3 przedstawia technikę przeładunku kontenera z pojazdu drogowego, lub placu składowania, na wózki pociągu bimodalnego.

\section{Wózki bimodalne bezadapterowe do transportu kon- tenerów}

Na rys. 4 pokazano kontenery na wózkach środkowych oraz układ wózka środkowego. Konstrukcja wózka środkowego jest zbliżona do wózka przeznaczonego do transportu naczep drogowych w systemie bimodalnym, przy poziomym przeładunku naczep. Zasadnicza różnica, to sposób oparcia i ryglowania kontenera w ramie półwózka.

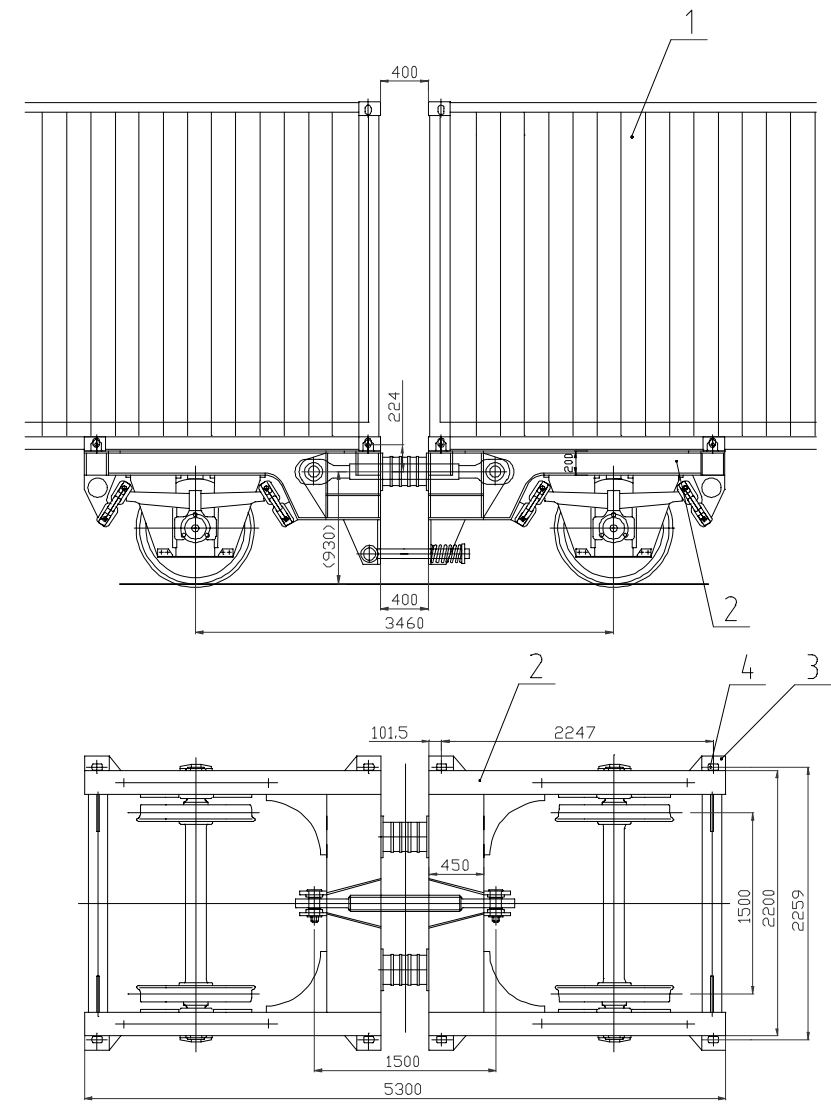

Rys.4. Kontenery na wózku środkowym

Kontener 1 opiera się na ramach półwózków 2 na ośmiu wspornikach $\mathbf{3}$ wyposażonych w trzpienie nasadowe 4 o budowie i zasadzie mocowania kontenera na ramie półwózka, podobnej jak dla typowych, dotychczas eksploatowanych kontenerów.

Na rys. 5 pokazano kontener zamocowany na wózku końcowym. Sposób oparcia i zamocowania kontenera na ramie wózka jest identyczny jak dla wózka środkowego. Typowy kontener jest zaopatrzony w osiem punktów mocowania na platformie wagonu lub ramie ciąnika drogowego, rozmieszczonych na narożach ramy kontenera. 
Aby przystosować typowy kontener do transportu na bimodalnych półwózkach kolejowych, należy go dodatkowo wyposażyć w cztery miejsca mocowania, rozstawione tak jak trzpienie nasadowe 4 zlokalizowane na ramie półwózka.

Standardowe kontenery ładunkowe serii 1 są zaopatrzone w znormalizowane naroża zaczepowe wykonane według wymagań normy PN-ISO 1161 [4]. Wymiary i maksymalne masy kontenerów ładunkowych serii 1 określono w normie PN-ISO 668 [5].
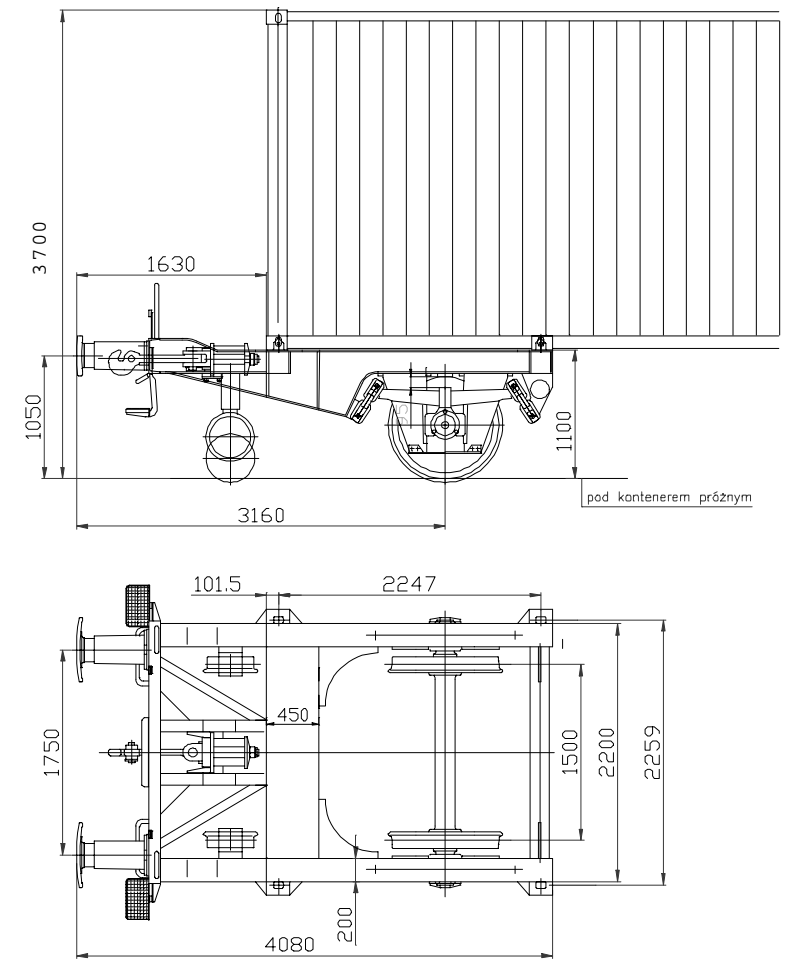

Rys.5. Kontener na wózku końcowym

Kontenery ładunkowe serii 1 charakteryzują się jednakową szerokością $2438 \mathrm{~mm}$ i różnią się między sobą długością i wysokością w poszczególnych grupach klasyfikacji.

W tej serii kontenerów znajdują się kontenery 40', 30 ', 20' i 10', których długości podano w tabeli 1 .

Długość kontenerów serii 1

Tabela 1

\begin{tabular}{|c|c|}
\hline Kontener & Długość $\mathbf{~ m m}$ \\
\hline $40^{\prime}$ & 12192 \\
$30^{\prime}$ & 9125 \\
$20^{\prime}$ & 6058 \\
$10^{\prime}$ & 2991 \\
\hline
\end{tabular}

Kontenery ładunkowe serii 2 sklasyfikowane wg karty UIC 592-2 [6] mają długości takie jak kontenery serii 1 , natomiast maksymalna szerokość kontenerów w każdej klasie $\left(10^{\prime}, 20 ', 30^{\prime}, 40 '\right)$ nie może być większa niż 2600 mm, a maksymalna wysokość nie może przekroczyć 2600 $\mathrm{mm}$.

Rozstaw osi zestawów kołowych dla pociągu złożonego z kontenerów 40' wynosi $9120 \mathrm{~mm}$, a dla pociągu z kontenerami 30', $6053 \mathrm{~mm}$. Z tego względu, jak również z uwagi na optymalizację ilości wózków w kontenerowym pociągu bimodalnym, należy założyć, że w systemie bimodalnym byłby opłacalny transport kontenerów najdłuższych to znaczy 40 stopowych.

Na rys. 6 pokazano pociąg bimodalny złożony z kontenerów $40^{\prime}$ i $30^{\prime}$.

Wymagania karty UIC 597 [7] w punkcie 1.6.2. określają minimalną wytrzymałość konstrukcji naczepy bimodalnej, które to przepisy muszą być również spełnione w przypadku transportu kontenerów na wózkach bimodalnych. Przepisy te dotyczą przede wszystkim wytrzymałości konstrukcji na siły wzdłużne oraz dopuszczalnej strzałki ugięcia kontenera w stanie obciążonym w uformowaniu kolejowym.

Minimalna siła wzdłużna, jaką winna wytrzymać konstrukcja nośna kontenera oraz elementy łączące kontener z ramą półwózka, wynosi $850 \mathrm{kN}$. Zaleca się, aby konstrukcja kontenera wytrzymała siły wzdłużne $1000 \mathrm{kN}$.

W systemie oparcia kontenera na ramie półwózka przewidziano cztery punkty mocowania kontenera na ramie każdego półwózka.

Z uwagi na możliwe wykonanie $\mathrm{z}$ określoną tolerancją rozstawów wzdłużnych trzpieni nasadowych na ramie półwózka jak i rozstawów wzdłużnych naroży zaczepowych wykonanych $\mathrm{w}$ ramie kontenera, należy założyć, że siły wzdłużne będą przenoszone $\mathrm{z}$ ramy półwózka na ramę kontenera przez dwa trzpienie nasadowe współpracujące $z$ dwoma narożami zaczepowymi. Według wymagań normy PN-ISO 1161 dwa naroża zaczepowe kontenera są przystosowane do przeniesienia siły wzdłużnej obliczonej wg wzoru $\mathrm{P}=2 \mathrm{~g} \cdot 1 \mathrm{R}$ gdzie:

$\mathrm{P}$ - siła wzdłużna przenoszona przez dwa naroża zaczepowe kontenera,

$\mathrm{g}$ - przyspieszenie ziemskie,

$\mathrm{R}$ - masa kontenera brutto.

Masa brutto kontenera 40' wynosi 30480 kg wg PNISO 668. Karta UIC 592-2 dopuszcza dla kontenerów 20, 30 i 40 stopowych zwiększenie masy maksymalnej do $34000 \mathrm{~kg}$. Tak więc maksymalna siła wzdłużna, jaka może być dopuszczona dla naroży zaczepowych kontenerów standardowych przy masie max $34000 \mathrm{~kg}$ wynosi:

$\mathrm{P}=2 \cdot 9,81 \cdot 34000 \cdot 0,1 \cdot 0,01 \approx 667 \mathrm{kN}$

$\mathrm{Z}$ przeprowadzonej analizy wynika, że standardowe kontenery nie spełniają wymagań karty UIC 597 w zakresie zdolności do przenoszenia sił wzdłużnych, jakie występują w eksploatacji pociaggu bimodalnego. Dla adaptacji istniejących kontenerów do transportu bimodalnego należy je wyposażyć dodatkowo w cztery miejsca mocowania oraz dokonać zmiany konstrukcji naroży zaczepowych i konstrukcji ramy nośnej kontenera, aby ich wytrzymałość umożliwiała przejęcie sił wzdłużnych o wartości minimum $\pm 1000 \mathrm{kN}$.

\section{Wózki bimodalne adapterowe do transportu kontene- rów}

Przeprowadzona analiza konstrukcyjna wykazała możliwość wykorzystania również taboru bimodalnego adapterowego do transportu kontenerów. Zastosowanie adapterowej techniki bimodalnej do przewozów kontenerów wymaga odpowiedniego przystosowania konstrukcji adapterów i kontenerów, do pionowego załadunku na wózki kolejowe wyposażone w adaptery.

Na rys.7. pokazano adapterowe wózki bimodalne załadowane kontenerami 40 stopowymi. 

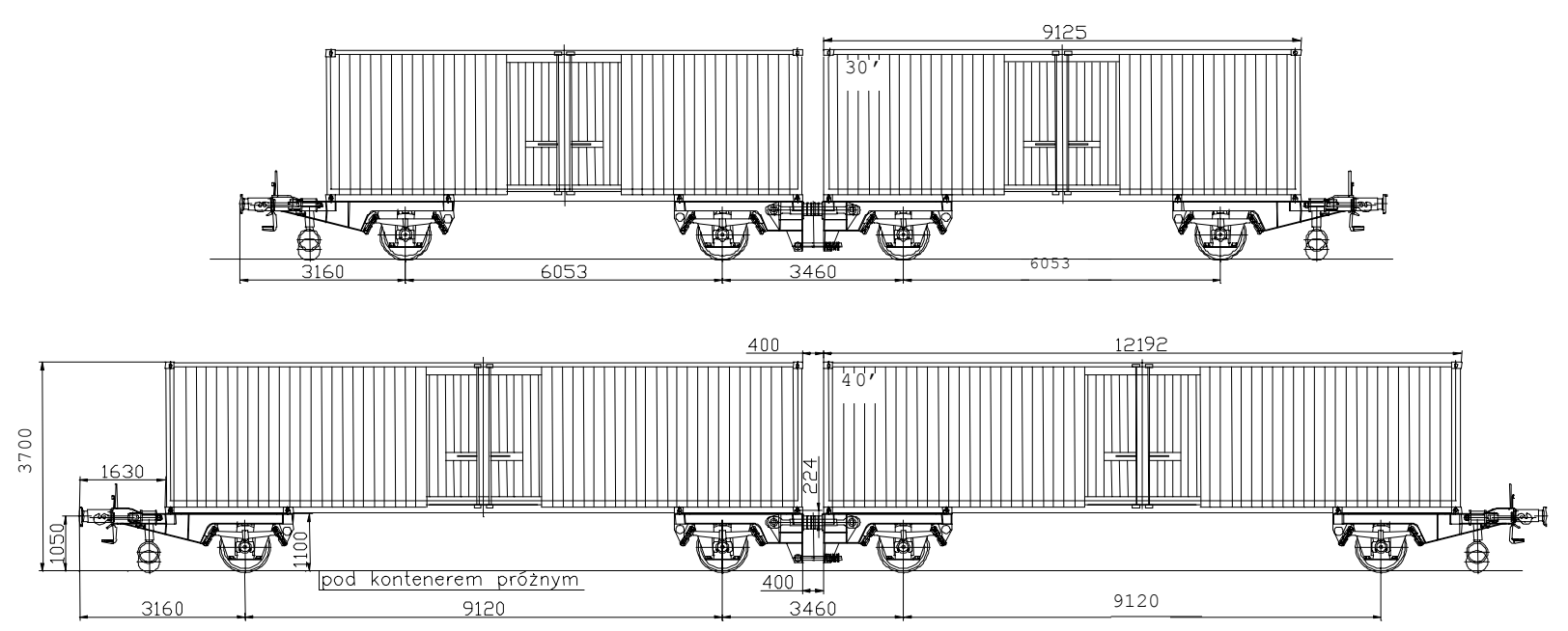

Rys.6. Kontenery 40' i 30' na bezadapterowych wózkach bimodalnych

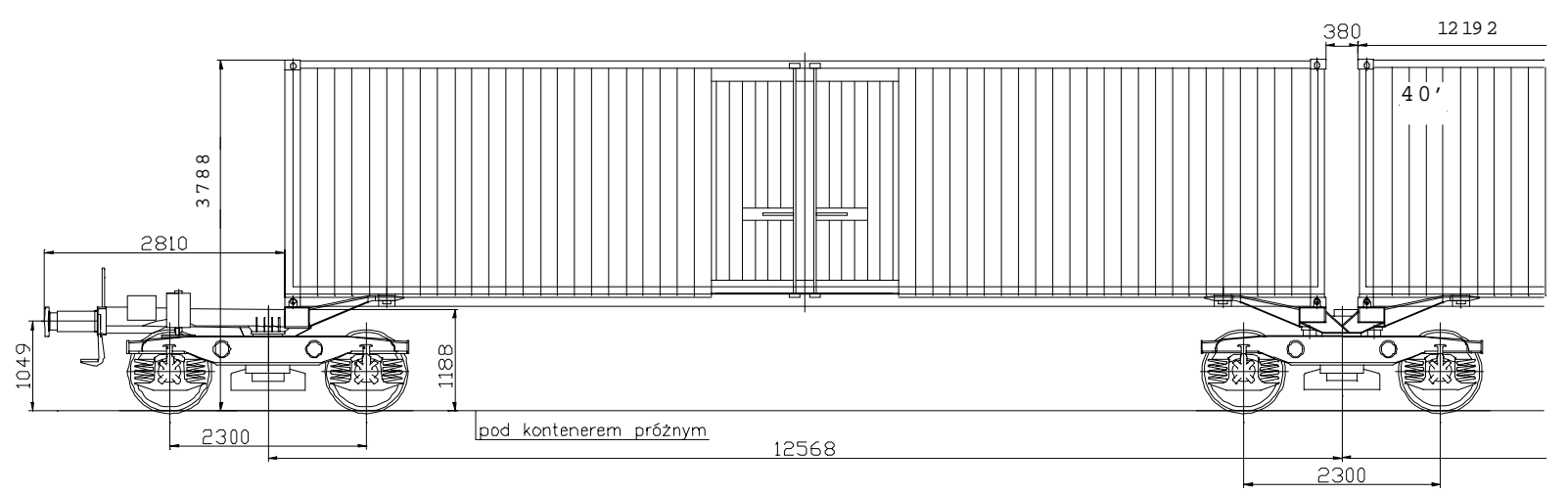

Rys.7. Kontenerowy pociąg bimodalny na wózkach wyposażonych w adaptery

Adapterowe wózki bimodalne środkowy i końcowy przedstawiono w rzucie poziomym na rys. 8.

a.

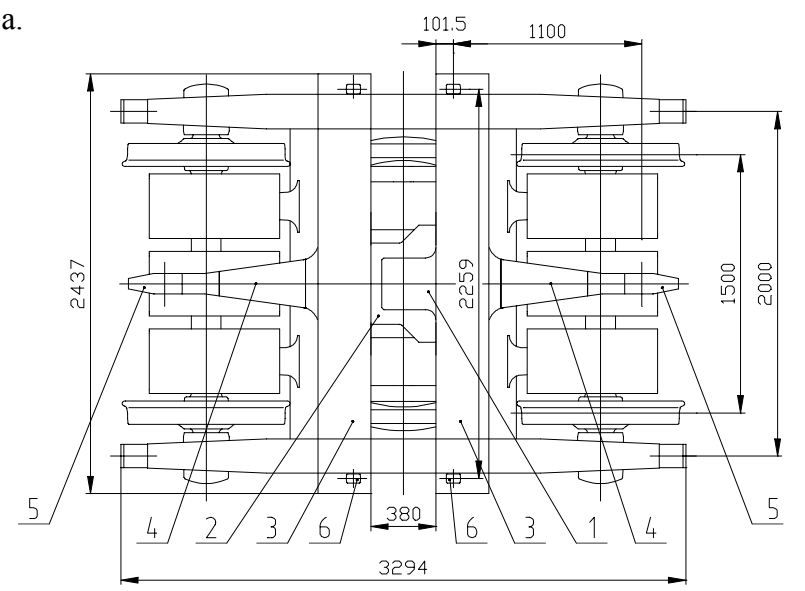

b.

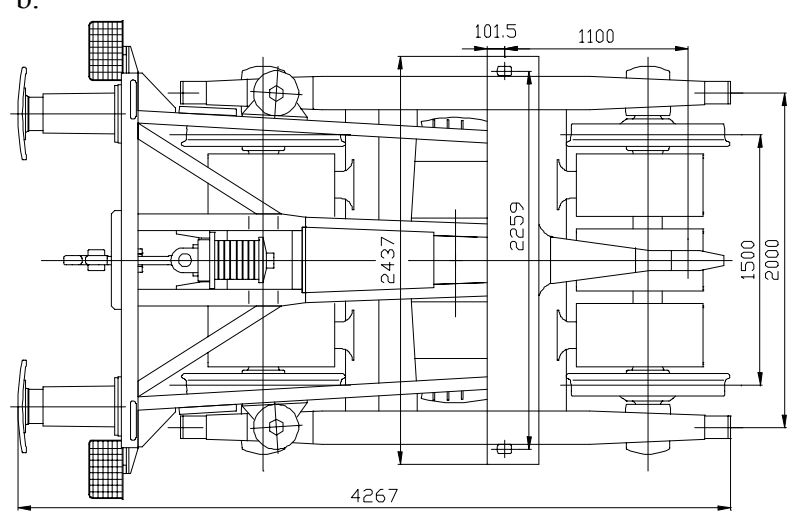

Rys.8. Adapterowe wózki bimodalne: a - wózek środkowy, b - wózek końcowy

Wózek środkowy ma symetryczny adapter górny 1 i dolny 2, który opiera się na wózku kolejowym na czopie skrętu oraz czterech ślizgach bocznych, w sposób identyczny jak w rozwiązaniu dla taboru bimodalnego do transportu naczep drogowych $\mathrm{z}$ poziomym przeładunkiem naczep. Adapter górny i dolny składa się z poprzecznej belki nośnej
3 oraz belki podłużnej 4 zakończonej dyszlem 5. Na obu końcach poprzecznej belki 3 górnego i dolnego adaptera umieszczono odpowiednio rozstawione trzpienie nasadowe 6. Na rys.9 przedstawiono przykład możliwego rozwiązania oparcia i zamocowania kontenera na adapterze wózka środkowego. 

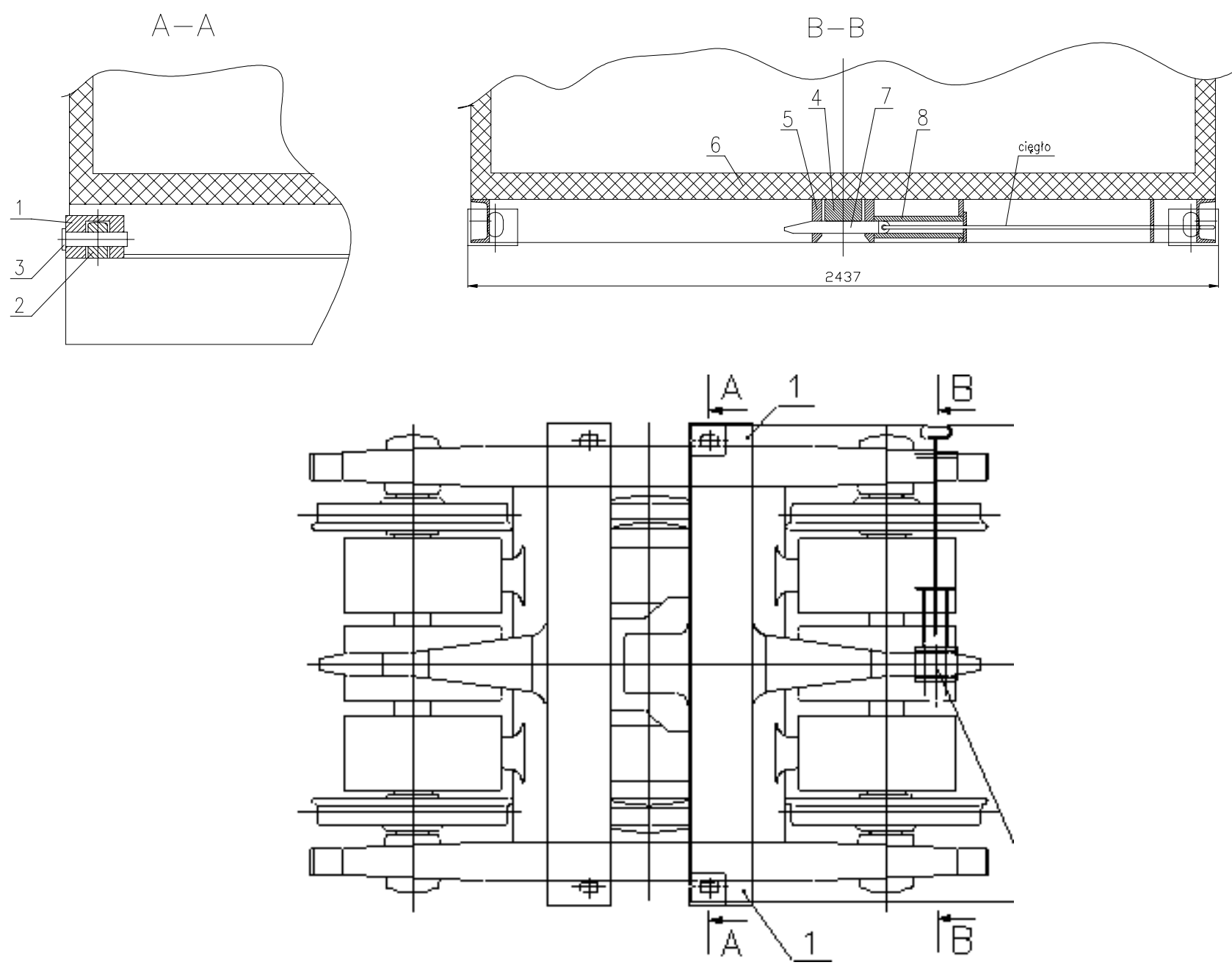

Rys.9. Oparcie i zamocowanie kontenera na adapterze wózka środkowego

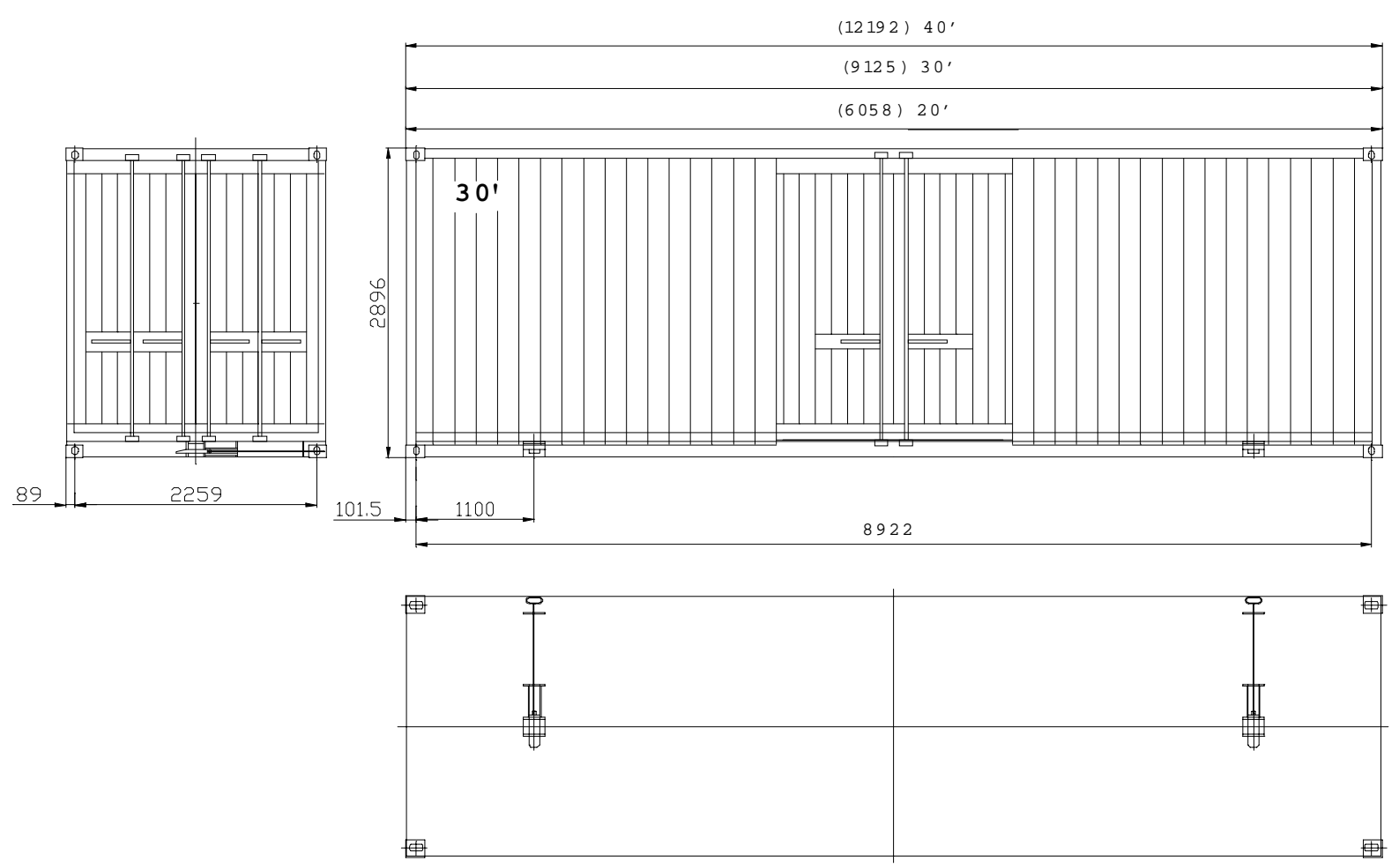

Rys.10. Kontener do transportu bimodalnego na wózkach wyposażonych w adaptery 
Kontener jest oparty i zamocowany na adapterze w trzech punktach, na dwóch siodłach trzpieni nasadowych 1 oraz na dyszlu 5 związanym z belką podłużną adaptera. Sposób oparcia i ryglowania kontenera na siodłach trzpieni nasadowych i na dyszlu adaptera pokazano na przekrojach A-A i B-B.

Kontener oparty jest na belce poprzecznej adaptera na dwóch narożach zaczepowych 1, w których umieszczone są trzpienie nasadowe 2. Do zabezpieczenia kontenera na belce adaptera przewidziano sworznie 3 .

Dyszel adaptera jest umieszczony we wnęce prowadzącej 5 i jest oparty górną powierzchnią o podłogę 6 kontenera, a od dołu jest zaryglowany klinem 7. Klin 7 zamontowano w prowadnicy 8 , w której mieści się po odryglowaniu dyszla.

W prezentowanym przykładzie ryglowania kontenera na adapterze mechanizmy ryglujące są zabudowane $\mathrm{w}$ kontenerze.

Zgodnie z zaleceniem karty UIC 597 należy dążyć do takiego rozwiązania konstrukcji docelowej, aby urządzenia ryglujące były zamontowane na adapterze ze względu na lepszą możliwość prowadzenia nadzoru stanu technicznego urządzeń ryglujących, które mają bezpośredni wpływ na bezpieczeństwo ruchu pociągu bimodalnego.

$\mathrm{Na}$ rys.10 pokazano przykład kontenera przystosowanego do transportu bimodalnego w systemie adapterowym.

\section{Literatura:}

[1] Medwid M.:Zmodernizowany tabor do transportu bimodalnego przystosowany do prędkości $160 \mathrm{~km} / \mathrm{h}$. Pojazdy Szynowe 2/2002.

[2] Medwid M.:Możliwości zastosowania bezadapterowego systemu transportu bimodalnego typu TABOR II do przewozu naczep o powiększonej wysokości przestrzeni ładunkowej. Pojazdy Szynowe 1/2004

[3] Karta UIC 432 Wagony towarowe. Prędkości jazdy. Warunki techniczne, które należy spetnić. Wydanie $01.2002 r$.

[4] Polska Norma PN-ISO 1161. Kontenery ładunkowe serii 1. Naroża zaczepowe. Wymagania. Kwiecień 1999r.

\section{Podsumowanie}

W wyniku przeprowadzonej technicznej analizy wykazano, że w systemie bimodalnym bezadapterowym jak i adapterowym jest możliwy transport kontenerów i innych pojemników wymiennych, w tym naczep samochodowych, z zastosowaniem pionowego przeładunku jednostek ładunkowych ze środków transportu drogowego na szynowy i odwrotnie.

Jednostki ładunkowe takie jak kontenery, naczepy samochodowe plandekowe, skrzyniowe i zbiornikowe oraz inne pojemniki muszą być przystosowane do ich połączenia z taborem kolejowym bimodalnym, jak również muszą spełniać wymagania wytrzymałościowe punktu 1.6.2 karty UIC 597.

Prostota konstrukcji taboru bimodalnego, zwłaszcza bezadapterowego, jak i spodziewane korzyści eksploatacyjne winny być wystarczająco mocnym argumentem dla podjęcia prac naukowo-badawczych nad wdrożeniem do eksploatacji proponowanych technologii transportu towarów w ruchu kombinowanym i bimodalnym. W pierwszym etapie prac należałoby opracować koncepcyjnie nowe rozwiązania techniczne i wykonać wstępną analizę ekonomiczną opłacalności wdrożenia proponowanych technologii transportu.

[5] Polska Norma PN-ISO 668. Kontenery tadunkowe serii 1. Klasyfikacja, wymiary i maksymalne masy brutto. Marzec 1999r.

[6] Karta UIC 592-2.Kontenery wielkie do przewozu na wagonach towarowych. Warunki techniczne dla kontenerów wielkich dopuszczonych do międzynarodowego przewozu ładunków. Wydanie 1.07.1996r.

[7] Karta UIC 597. System transportu kombinowanego szynowo - drogowego. Naczepy wózkowe. Charakterystyki. Wyd. 1 nakład z 01.07.1993. 